\title{
Effect of dopamine agonist medication on prolactin producing pituitary adenomas
}

\section{A morphological study including immunocytochemistry, electron microscopy and in situ hybridization}

\author{
K. Kovacs ${ }^{1}$, L. Stefaneanu ${ }^{1}$, E. Horvath ${ }^{1}$, R.V. Lloyd ${ }^{2}$, I. Lancranjan ${ }^{3}$, M. Buchfelder ${ }^{4}$, and R. Fahlbusch ${ }^{4}$ \\ ${ }^{1}$ Department of Pathology, St. Michael's Hospital, University of Toronto, Toronto, Ontario, Canada \\ ${ }^{2}$ Department of Pathology, University of Michigan, Ann Arbor, Michigan, USA \\ ${ }^{3}$ Division of Neuroendocrinology, Sandoz Pharmaceutical, Basel, Switzerland \\ ${ }^{4}$ Department of Neurosurgery, University of Erlangen-Nürnberg, Erlangen, Federal Republic of Germany
}

Received September 4, 1990 / Accetped November 19, 1990

Summary. Conventional light microscopy, immunocytochemistry, electron microscopy and in situ hybridization were used to evaluate the effect of dopamine agonists (bromocriptine-LAR and bromocriptine) on the morphology of surgically removed prolactin (PRL)-producing pituitary adenomas. Dopamine agonist therapy resulted in decrease of serum PRL, clinical improvement and tumour shrinkage. Using light and electron microscopy cellular atrophy, interstitial and perivascular fibrosis were noted; in several tumours connective tissue accumulation was pronounced. The cellular response was not uniform. In some adenomas populations of large cells and small cells were distinguished. The large cells contained immunoreactive PRL and expressed the PRL gene indicating resistance to dopamine agonists. It appears that these cells retained the potential to secrete PRL and proliferate despite exposure to dopamine agonists. In the small cells, PRL immunoreactivity and PRL gene expression decreased providing evidence that both PRL release and synthesis were blocked. Small cells can persist in tumours after discontinuation of dopamine agonist medication suggesting these small cells are irreversibly suppressed and are not capable of regaining their endocrine function and proliferative capability. The formation of irreversibly suppressed PRL cells may explain why some PRL-producing adenomas do not recur after withdrawal of dopamine agonists.

Key words: Bromocriptine - Pituitary neoplasm - Prolactin - Ultrastructure

Offprint requests to: $\mathrm{K}$. Kovacs, Department of Pathology, St. Michael's Hospital, 30 Bond Street, Toronto, Ontario, M5B 1W8, Canada

\section{Introduction}

A large number of studies have provided conclusive evidence that dopamine agonist drugs decrease serum prolactin (PRL) levels, stop amenorrhoea and galactorrhoea, restore fertility and libido and cure impotence and hypogonadism in patients with PRL-producing pituitary adenoma (Barrow et al. 1984; Corenblum 1985; Corenblum and Taylor 1983; Johnston et al. 1983; Jordan and Kohler 1987; Molitch 1989; Molitch et al. 1985; Nabarro 1982; Vance and Thorner 1987). Beside the marked clinical and biochemical improvement, substantial tumour shrinkage has also been documented (Bassetti et al. 1984; Chiodini et al. 1981; Corenblum and Hanley 1981; Fahlbusch et al. 1987; Hassoun et al. 1985; Landolt et al. 1987; McGregor 1979; Nillius et al. 1978; Rengachary et al. 1982; Saitoh et al. 1986; Schottke et al. 1986; Thorner et al. 1980). In most patients tumour involution is reversible, since after discontinuation of dopamine agonist medication the tumour regrows, serum PRL levels rise and the clinical signs and symptoms recur (Molitch et al. 1985; Thorner et al. 1981).

Despite the experience obtained in dopamine agonist therapy and the progress in understanding the mechanism of dopamine agonist action, several questions remain unresolved. It is not clear whether only PRL release or both release and synthesis are inhibited in human PRL-producing adenomas, nor is it known what are the mechanisms and sequence of events in tumour involution and regrowth. Further studies are required to clarify why some adenomas are resistant to dopamine agonist drugs (Bannister and Sheridan 1987; Breidahl et al. 1983; Cheyne et al. 1988; Kupersmith et al. 1989; Liuzzi et al. 1985; Molitch et al. 1985) whereas other 
tumours show inreversible shrinkage, serum PRL levels fail to increase and the clinical signs and symptoms do not return after withdrawal of dopamine agonist medication (Johnston et al. 1984; Moriondo et al. 1985; Wang et al. 1987; Zarate et al. 1983). Some of these questions were addressed by previous morphological investigations (Esiri et al. 1986; Hassoun et al. 1985; Horvath and Kovacs 1986; Horvath et al. 1988; Rengachary et al. 1982; Saitoh et al. 1986; Tindall et al. 1982); however, no definite conclusions were drawn.

The aim of the present study was to obtain a deeper insight into these problems by studying the tumours in detail using light microscopy, immunocytochemistry and electron microscopy. We correlated the morphology of dopamine agonist exposed PRL-producing adenomas with PRL gene expression, applying in situ hybridization.

\section{Patients and methods}

Twenty-two patients underwent trans-sphenoidal surgery for PRLsecreting pituitary adenomas. All patients had marked hyperprolactinaemia. Six patients received no dopamine agonist therapy. Seven patients were treated with one intramuscular injection of $100 \mathrm{mg}$ bromocriptine (2-bromo- $\alpha$-ergocryptine, BEC) LAR, a new long-acting repeatable injectable form of bromocriptine (Parlodel LAR, Sandoz, Basel, Switzerland). This drug was found to be effective in the management of patients with PRL-producing adenoma (Ciccarelli et al. 1987; Grossman et al. 1986; Montini et al. 1986; Schettini et al. 1988; van't Verlant et al. 1988). Nine patients were given bromocriptine $(2.5-7.5 \mathrm{mg})$ daily. In 6 of these patients, bromocriptine treatment was discontinued for at least 2 months before surgery. The duration of bromocriptine therapy varied from 3 weeks to 11 months. Serum PRL levels were measured before, during and after cessation of bromocriptine administration by radioimmunoassay. The clinical signs and symptoms were monitored and tumor sizes estimated by various imaging techniques.

Tumour tissues were fixed in buffered formalin and embedded in paraffin. Sections of $4-6 \mu \mathrm{m}$ were stained with haematoxylin and eosin (H\&E) and the periodic acid-Schiff (PAS) method. The avidin-biotin-peroxidase complex (ABC) technique was used for demonstration of hormone content. The following antisera were applied: anti-hGH (1:1500 dilution, DAKO, Santa Barbara, Calif.), anti-hPRL (1:4000 dilution, provided by Dr. H. Friesen, Department of Physiology, University of Manitoba, Winnipeg, Manitoba, Canada), anti-hACTH (1:2000 dilution), anti- $\beta$ hTSH (1:4000 dilution), anti- $\beta$ hFSH (1:2000 dilution); anti- $\beta \mathrm{hLH}$ ( $1: 2000$ dilution), all donated by NIDDKD (Bethesda, Md.); monoclonal anti $\alpha$-hSU (1:800 dilution, Biogenex, Dublin, Calif.). The immunostaining and the control stains were performed as described elsewhere (Asa et al. 1986).

For electron microscopy small pieces of the tumours were fixed in $2.5 \%$ glutaraldehyde, postfixed in $1 \%$ osmium tetroxide, dehydrated in graded series of ethanol, processed through propylene oxide and embedded in Epon-Araldite mixture. Ultrathin sections were stained with uranyl acetate and lead citrate and studied with a Philips 410-LS electron microscope.

Using in situ hybridization (ISH) for PRL mRNA and GH mRNA demonstration, oligonucleotide probes complementary to the region of hPRL $66-72$ and hGH 11-17 were exploited. The probes were synthesized on an automated DNA synthesizer (Gene Assembler) by Pharmacia (Milwaukee, Wis.) using the solid-phase beta cyanoethyl phosphor amidite method. The 3-end labelling method with 35-S was applied. The sequence of the probes and details of the procedures have been described previously (Kovacs et al. 1989).
ISH was performed on 5 - $\mu$ m-thick paraffin sections applying $5 \times 10^{5} \mathrm{cpm}$ of probe as described elsewhere. For combined ISH and immunocytochemistry for PRL the $\mathrm{ABC}$ method was carried out after $2 \times$ standard saline citrate (SSC: $0.15 \mathrm{MNaCl} / 0.015 \mathrm{M}$ trisodium citrate) washings (Kovacs et al. 1989). The following controls for ISH were performed: (1) predigestion of tissue sections with $100 \mathrm{ng} / \mathrm{ml}$ RNase A (Sigma, St. Louis, Mo); (2) competition studies with 100-fold excess of unlabelled probe to assure specificity; (3) human liver and parathyroid adenomas were used as negative controls.

\section{Results}

Biochemical, clinical and imaging findings will not be reported here and the effects of the two different dopamine agonists will not be compared; these results will be the subject of a clinical paper (Fahlbusch et al., in preparation). It suffice to say that dopamine agonist medication resulted in reduction of serum PRL levels in most cases, clinical improvement and varying degrees of pituitary adenoma shrinkage.

By light microscopy, the pituitary tumours represented chromophobic, slightly acidophilic adenomas. The adenomas removed from untreated patients had a diffuse growth pattern and were PAS negative. By immunocytochemistry, the presence of PRL with the characteristic disposition in the Golgi area was demonstrated in most adenoma cells.

In adenomas exposed to bromocriptine-LAR or bromocriptine up to surgery the most conspicuous changes were the decrease in size of tumour cells and the presence of interstitial and perivascular fibrosis. In several tumours accumulation of connective tissue was pronounced. The degree of cellular response to dopamine agonist varied not only from case to case but also, sometimes, within different areas of the same tumour (Table 1). The most marked morphological alterations were noted in two adenomas (cases 1 and 2) exposed to bromocriptine-LAR. The small PAS-negative adenoma cells possessed scanty cytoplasm around dark, heterochromatic nuclei and were arranged in small groups surrounded by abundant connective tissue; deposits of endocrine amyloid were seen in one of these adenomas; intense perivascular fibrosis was evident as well. PRL immunoreactivity was absent or weak and restricted to few adenoma cells. Three adenomas (cases 5, 8 and 9) displayed small cells, but fibrosis was limited to the perivascular areas and PRL immunopositivity was present in many cells. In four adenomas (cases 3, 4, 7 and 10) areas of small cells with dark nuclei alternated with groups of cells with euchromatic nuclei and PRL immunopositivity was restricted to the latter population of cells. Two adenomas (cases 6 and 7) were composed of cells with relatively large, lightly stained nuclei, and narrow cytoplasm containing evenly distributed PRL immunoreactivity.

Three adenomas removed from patients who had been off BEC for 2 or more months before surgery had the same morphology as untreated ones; PRL immunoreactivity was intense and present in most adenoma cells. In two adenomas (cases 3 and 4) marked cellular heterogeneity was evident: one adenoma was composed of 
Table 1. Summary of morphological results in prolactin (PRL)-producing adenomas from ten patients treated with dopamine agonists up to surgery

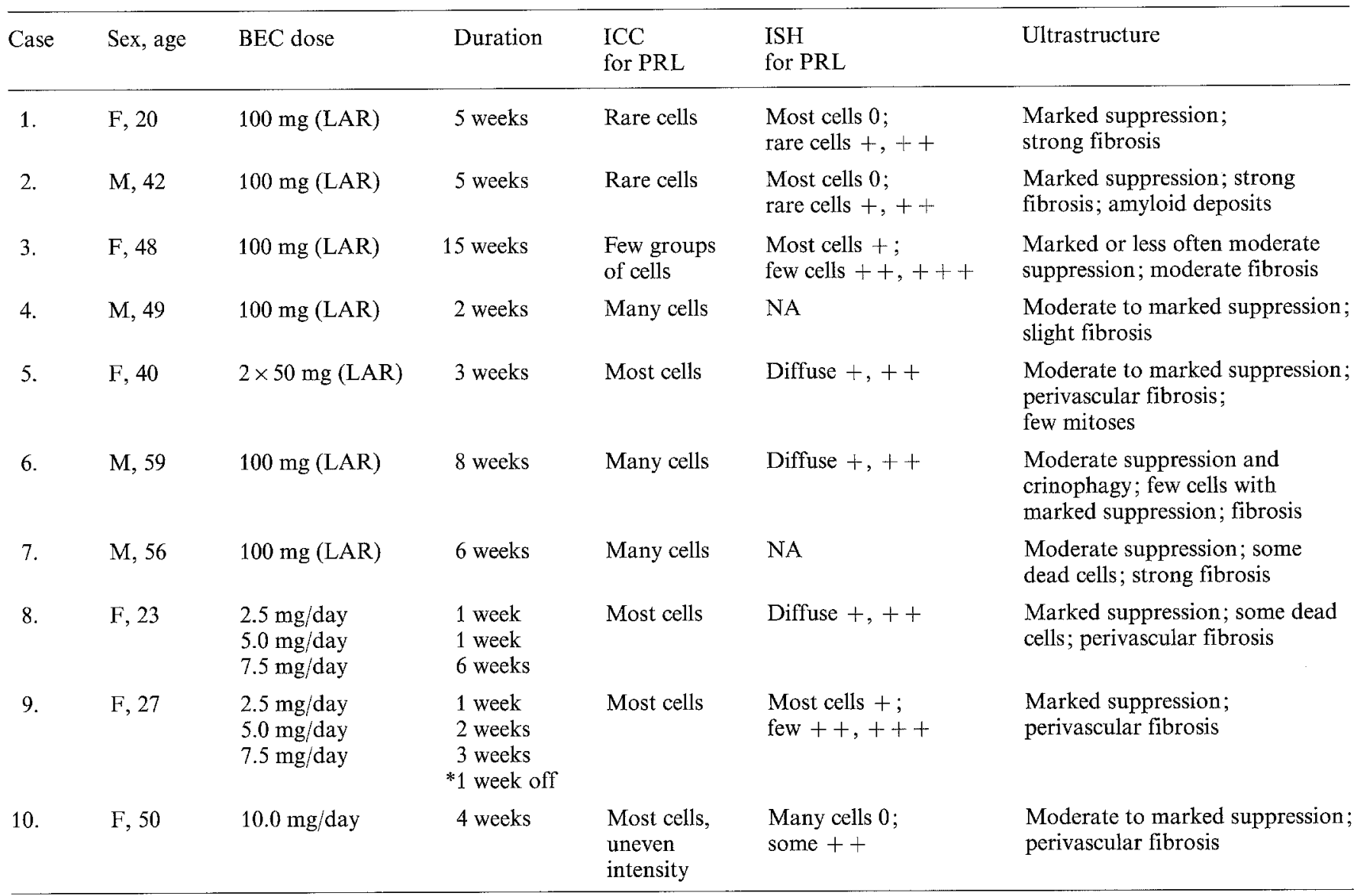

0 , negative labelling; + , weak labelling; ++ , moderate labelling; +++ , intense labelling; ++++ , very intense labelling; $\mathrm{NA}$ not available; BEC, 2-bromo- $\alpha$-ergocryptine; ICC, immunocytochemistry; ISH, in situ hybridization

Table 2. Summary of morphological results in six PRL-producing adenomas from patients who discontinued dopamine agonist therapy before surgery

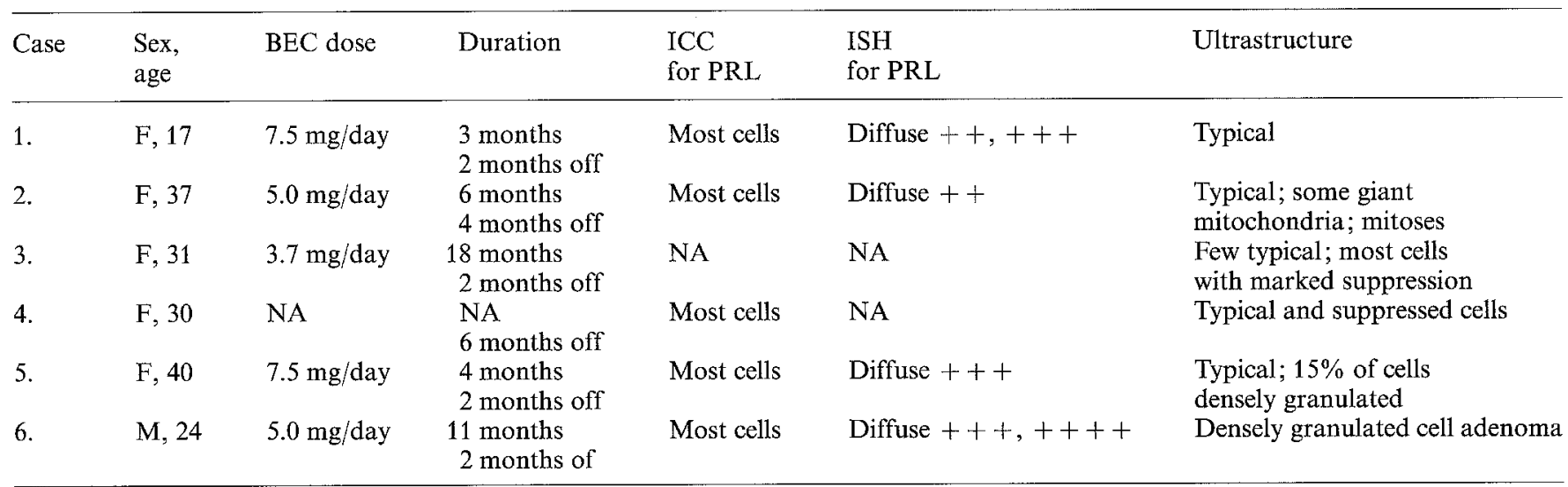

For legend, see Table 1

small cells with dark nuclei intermingled with large cells containing euchromatic nuclei; however, the PRL immunostaining was evenly distributed. The other adenoma exhibited large areas of small cells with dark nuclei and a minor population of large cells with euchromatic nuclei (Table 2). PRL immunopositivity was un- even and perivascular fibrosis was marked in this tumour.

On electron microscopy the six tumours removed from untreated patients showed the characteristic ultrastructural features of sparsely granulated PRL cell adenomas (Horvath and Kovacs 1986; Kovacs and Hor- 

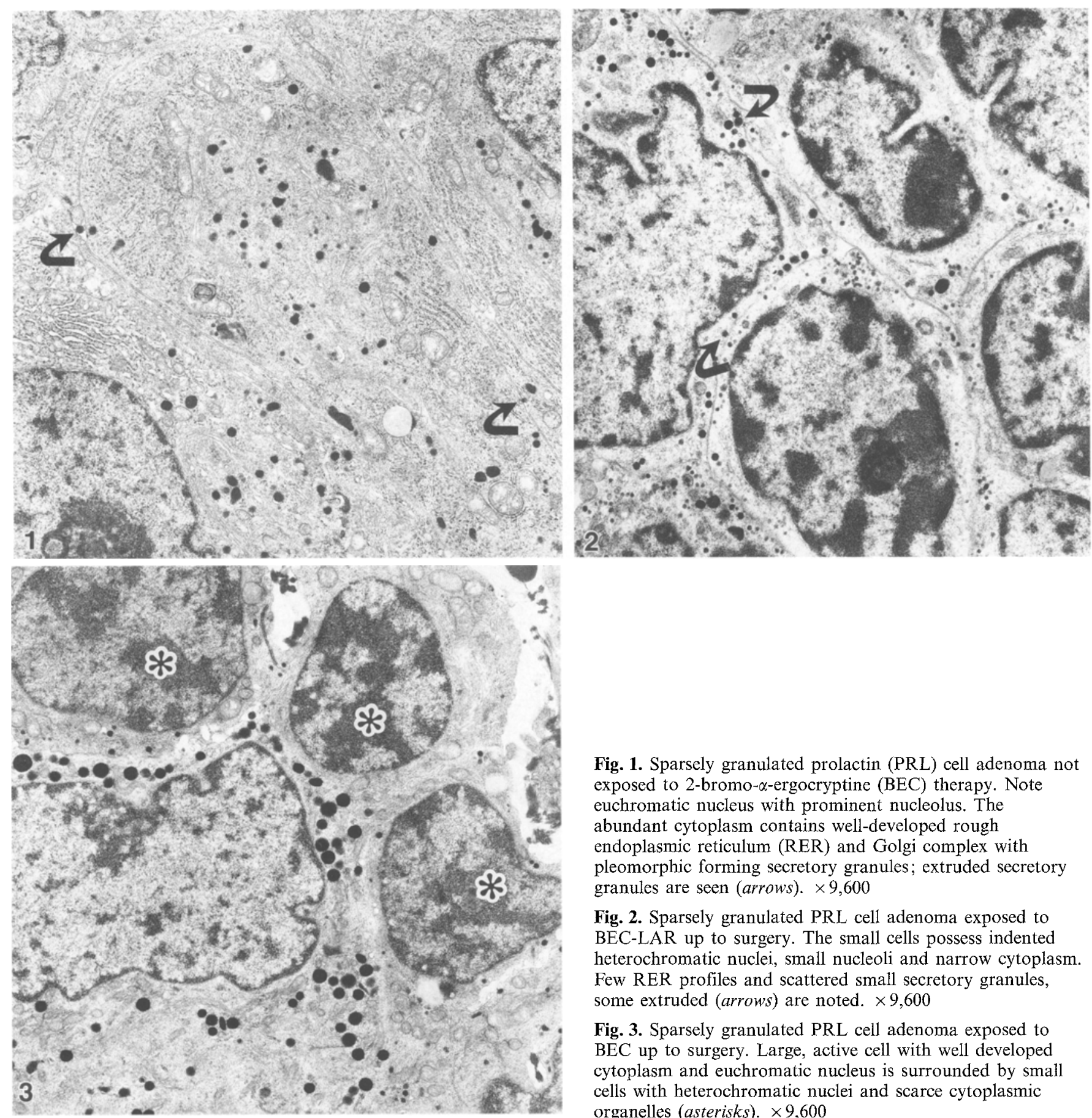

Fig. 1. Sparsely granulated prolactin (PRL) cell adenoma not exposed to 2-bromo- $\alpha$-ergocryptine (BEC) therapy. Note euchromatic nucleus with prominent nucleolus. The abundant cytoplasm contains well-developed rough endoplasmic reticulum (RER) and Golgi complex with pleomorphic forming secretory granules; extruded secretory granules are seen (arrows). $\times 9,600$

Fig. 2. Sparsely granulated PRL cell adenoma exposed to BEC-LAR up to surgery. The small cells possess indented heterochromatic nuclei, small nucleoli and narrow cytoplasm. Few RER profiles and scattered small secretory granules, some extruded (arrows) are noted. $\times 9,600$

Fig. 3. Sparsely granulated PRL cell adenoma exposed to BEC up to surgery. Large, active cell with well developed cytoplasm and euchromatic nucleus is surrounded by small cells with heterochromatic nuclei and scarce cytoplasmic organelles (asterisks). $\times 9,600$

vath 1986) (Fig. 1). The adenoma cells possessed euchromatic nuclei with prominent nucleoli and abundant cytoplasm. The rough endoplasmic reticulum (RER) was well developed, consisting of parallel cisternae or concentric whorls. Golgi complexes were prominent and contained pleomorphic developing granules. The cytoplasmic secretory granules were usually sparse, electrondense and measured 125-300 $\mathrm{nm}$. The extrusion of secretory granules into the intercellular space was a common event.

Five adenomas (cases 1, 2, 7-9) exposed to dopamine agonists up to surgery showed uniform, marked ultrastructural signs of functional suppression (Fig. 2). The very small, ovoid, slightly polyhedral adenoma cells contained smaller, often indented nuclei with coarsely clumped heterochromatin and small nucleoli. The narrow rim of cytoplasm contained scanty RER and few free ribosomes. In most adenoma cells, the Golgi complex was not recognizable. When it was noticeable, it was formed by few collapsed sacculi and numerous vesicles with occasional small forming granules. The majority of secretory granules were very small, measuring 50 
$200 \mathrm{~nm}$, but few of them reached $300 \mathrm{~nm}$. Misplaced exocytoses of one or multiple secretory granules were frequently encountered.

Three adenomas (cases 3-5) consisted of sparsely granulated cells with ultrastructural signs of marked, or often moderate suppression. The small polyhedral cells contained irregular nuclei with discrete or moderate heterochromatinization and nucleoli with variation in size. Beside the adenoma cells with small cytoplasm, occasional adenoma cells with large, well-differentiated cytoplasm and secretory granules measuring up to $450 \mathrm{~nm}$ were seen (Fig. 3).

One sparsely granulated PRL cell adenoma (case 6) was composed of small cells with long cytoplasmic processes. The relatively large nuclei contained stippled heterochromatin and moderately developed nucleoli. The narrow cytoplasm harbored poorly to moderately developed RER and Golgi apparatus. The sparse secretory granules were small and many were engaged in exocytosis. In case 7, the adenoma contained cells with heterochromatic nuclei but fairly prominent nucleoli. In the narrow cytoplasm a surprisingly abundant RER, active Golgi region and quite numerous small secretory granules were present.

The ultrastructure of adenomas of patients in whom bromocriptine was discontinued showed some variations (Table 2). Two adenomas (cases 1 and 2) had the same ultrastructure as those not exposed to the drug. Case 5 was composed of a predominant population of typical sparsely granulated PRL cells and a minor component (approximately $15 \%$ ) of densely granulated PRL cells with secretory granules measuring up to $900 \mathrm{~nm}$. One tumour (case 6) represented densely granulated PRL cell adenoma. The abundant spherical secretory granules measured 150-600 nm. Many adenoma cells showed extrusion of secretory granules. The cytoplasmic organelles involved in hormone synthesis were well developed as in the sparsely granuled variant. Lysosomes and crinophagy were frequently encountered. Two tumours (cases 3 and 5) had heterogeneous ultrastructural features with adenoma cells showing considerable variation in shape and size. In one adenoma some nuclei were
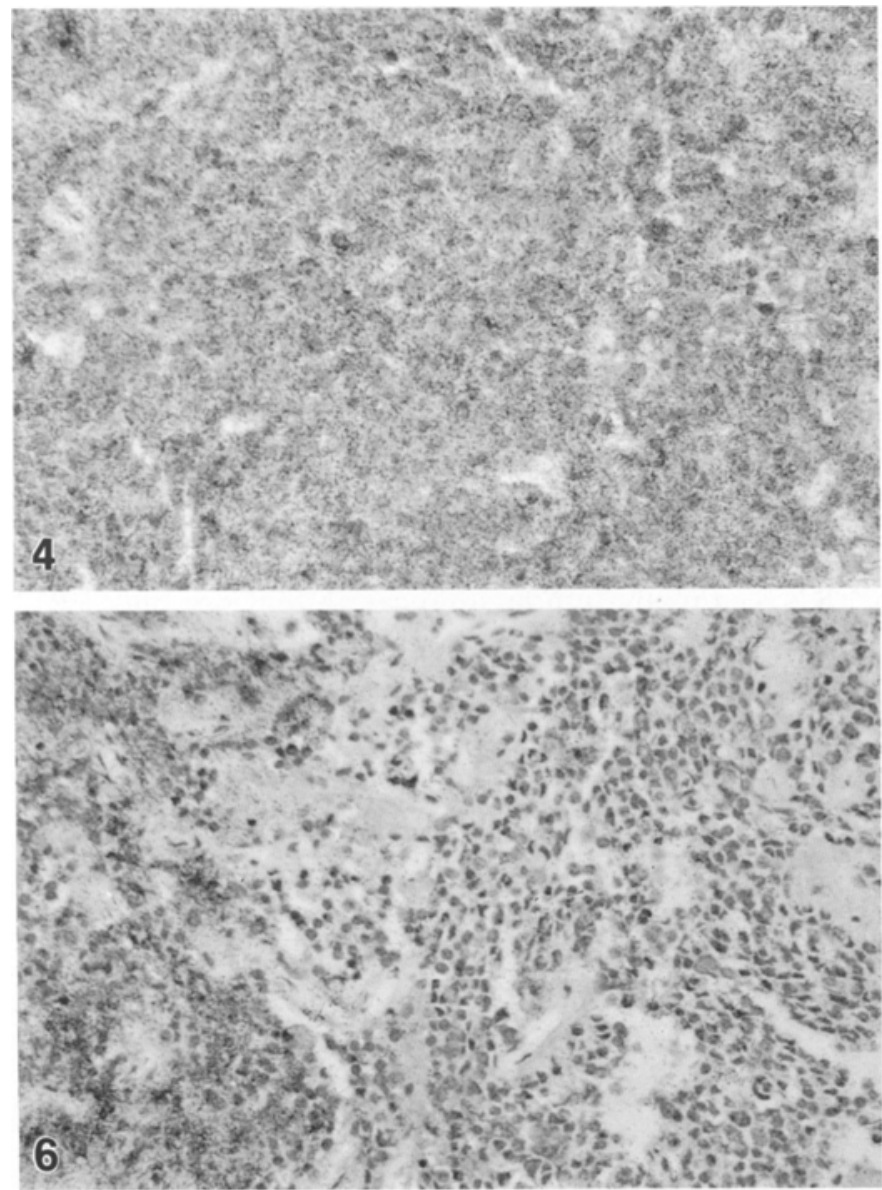

Fig. 4. PRL cell adenoma unexposed to BEC. Most cells are immunoreactive for PRL and have an even, intense distribution of PRL mRNA. $\times 400$

Fig. 5. PRL cell adenoma exposed to BEC-LAR up to surgery shows marked functional suppression as indicated by the lack of both PRL gene expression and gene product. $\times 400$
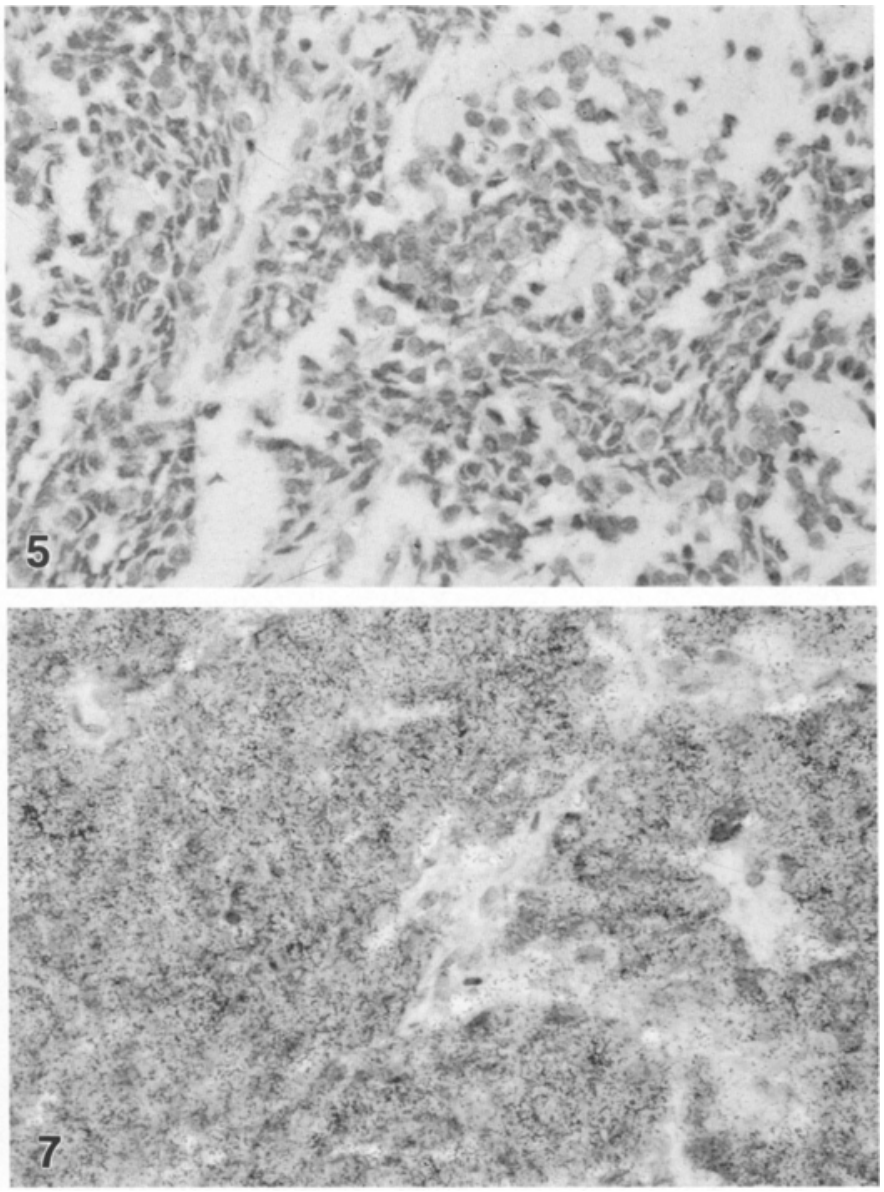

Fig. 6. PRL cell adenoma with an uneven reponse to BEC: the PRL immunoreactive cells contain abundant PRL mRNA, while cells devoid of PRL lack its messenger, as well. $\times 400$

Fig. 7. PRL cell adenoma in which BEC therapy was discontinued 2 months before surgery shows the same pattern of PRL immunoreactivity and intensity of PRL $\mathrm{mRNA}$ as seen in adenoma unexposed to BEC. $\times 400$ 
euchromatic, while others had coarsely clumped heterochromatin; there were marked variations in size of the cytoplasm and prominence of RER and Golgi complexes; in many adenoma cells secretory granules were sparse and measured up to $300 \mathrm{~nm}$; in some adenoma cells the secretory granules were larger and more numerous than usual. In the other adenoma, most of the cells had hyperchromatic nuclei and small rim of cytoplasm with few organelles.

Using ISH, none of the PRL-producing adenomas examined expressed the GH gene. All six untreated PRL cell adenomas contained an intense or very intense hybridization signal for PRL mRNA (Fig. 4). In adenomas exposed to dopamine agonists a marked decrease in PRL mRNA content was found when compared with the untreated (Table 1). Among PRL cell adenomas with signs of marked suppression, the lowest signal level was found in two adenomas treated with bromocriptine-LAR. In these tumours most adenoma cells were devoid of PRL mRNA (Fig. 5). In the other adenomas, including those in which moderate morphological response was predominant, a weak or mild hybridization signal level prevailed. ISH combined with immunocytochemistry revealed that in tumours with uneven PRL immunoreactivity, PRL mRNA was usually abundant in PRL immunopositive cells and scanty or absent in the adenoma cells which failed to stain for PRL (Fig. 6).

In adenomas in which bromocriptine therapy was discontinued a few months before surgery, the intensity of labelling for PRL mRNA was comparable with that of untreated adenomas (Table 2) (Fig. 7). A high level of mRNA was found in both sparsely and densely granulated adenoma cells. In the two tumours with different degrees of suppression, ISH revealed adenoma cells with variable intensity of labelling for PRL $m$ RNA and adenoma cells lacking the messenger.

\section{Discussion}

The present investigation confirms and extends previous findings and provides conclusive evidence that treatment with dopamine agonists causes profound morphological alterations in PRL-producing pituitary adenomas (Hassoun et al. 1985; Horvath and Kovacs 1986; Horvath et al. 1988; Saitoh et al. 1986; Schottke et al. 1986; Tindall et al. 1982). In earlier studies (Tindall et al. 1982) dopamine agonist medication was found to induce marked cellular involution manifested by reduction of cellular, cytoplasmic, nuclear and nucleolar sizes, increase of nuclear-cytoplasmic ratio and decrease of cytoplasmic volume densities of endoplasmic reticulum and Golgi complexes. Compared to PRL producing adenomas removed from patients not exposed to dopamine agonists, the cytoplasmic volume densities of mitochondria and in many cases, those of the lysosomes exhibited no major change and the cytoplasmic volume densities and diameters of secretory granules showed slight increase in some adenomas and no change or slight decrease in others. In a few tumours accumulation of lysosomes was noted especially in those in which cellular shrinkage was not marked. Although no morphometry was applied in the present study, the cellular involution was obvious. The clinical and biochemical results were concordant with the morphological alterations and were manifested by decrease of serum PRL levels as well as restoration of menstruation, cure of galactorrhoea, hypogonadism and impotence and improvement of libido. Tumour shrinkage was documented before surgery by various imaging techniques.

Apart from the morphological changes affecting the adenoma cells varying degrees of interstitial and perivascular fibrosis was noted by previous workers (Esiri et al. 1986; Landolt and Osterwalder 1984) and in the present study. A marked individual difference was evident among various tumours. Accumulation of connective tissue was more pronounced in the tumours of patients who had protracted dopamine agonist medication with relatively large doses and in whom tumour shrinkage was extensive. The factors accounting for the development of fibrosis are not known. No widespread cellular death was evident; thus it is unlikely that extensive necrosis preceded and was responsible for the accumulation of connective tissue. It may be that mediators were released from the shrinking tumour cells which evoke proliferation of connective tissue. This interpretation is, however, speculative and is not supported by any evidence so far.

Similar to the clinical and biochemical results the morphological changes were found to be reversible in many tumours. In some tumours following withdrawal of dopamine agonist medication the structural features were indistinguishable from those removed from patients not receiving dopamine agonist drugs. In these tumours the adenoma cells were large, possessing abundant cytoplasm, conspicuous endoplasmic reticulum network, many free ribosomes and polysomes and prominent Golgi complexes.

Hybridization histochemistry using an oligonucleotide probe demonstrated a marked decrease of PRL mRNA in many tumours indicating that not only PRL release but also PRL synthesis was suppressed by dopamine agonist medication. These results, using ISH methodology, are in agreement with previous findings obtained in animal pituitaries which showed a significant reduction of PRL gene expression secondary to dopamine agonist exposure (Maurer 1980).

A marked individual variation in the cellular response to dopamine agonist medication was a striking finding in the present study. In some tumours removed from patients treated with dopamine agonists two different cell populations were clearly identified; one seemed to have escaped dopamine agonist suppression. These adenoma cells were large, their PRL content was not decreased and PRL gene expression appeared to be within the normal range. The other cell population consisted of small cells exhibiting the effect of dopamine agonist suppression characterized by marked cellular involution, decrease of immunoreactive PRL content and PRL mRNA

The finding that differences exist in cellular responsiveness to dopamine agonists is difficult to explain. It may be that functional dopamine receptors (Bression 
et al. 1980; Bronin 1982; Koga et al. 1987) are missing on the surface of some adenomatous PRL cells or impairment of some intracellular event accounts for the resistance to dopamine agonists. The degree of clinical and biochemical resistance depends on the number of unresponsive large cells which are capable of expressing the PRL gene and its product and presumably have a potential for growth despite exposure to dopamine agonists. If unresponsive large cells predominate in a tumour exposed to dopamine agonist medication, little suppressive effect can be expected from the drug.

It has been noted by several authors that some patients are resistant to dopamine agonist therapy (Bannister and Sheridan 1987; Breidahl et al. 1983; Cheyne et al. 1988; Kupersmith et al. 1989; Liuzzi et al. 1985; Molitch et al. 1985). In other patients tumour involution is permanent, tumour regrowth fails to occur and hyperprolactinaemia as well as the clinical symptoms do not revert after discontinuation of dopamine agonist medication (Johnston et al. 1984; Moriondo et al. 1985; Wang et al. 1987; Zarate et al. 1983). It appears that such tumours are composed of markedly suppressed small PRL cells that are not able to secrete PRL in excess and do not continue to proliferate. It is conceivable that those small cells which contain no immunoreactive PRL and do not express the PRL gene even after discontinuation of dopamine agonist therapy lose the potential to regain endocrine activity and growth, in some cases irreversibly. The development of a clone of irreversibly suppressed PRL cells may provide an explanation of why some adenomas do not cause hyperprolactinaemia and do not regrow after withdrawal of dopamine agonist medications.

Acknowledgements. This work was supported in part by grant MT6349 awarded by the Medical Research Council of Canada. The authors wish to thank Mrs. N. Ryan, Mrs. J. Karpenko, and Mrs. D. Lietz for their contribution in the morphological study and Mrs. M. Pasnik for the secretarial work.

\section{References}

Asa SL, Gerry BM, Singer W, Horvath E, Kovacs K, Smyth HS (1986) Gonadotropin secretion in vitro by human pituitary null cell adenomas and oncocytomas. J Clin Endocrinol Metab 62:1011-1019

Bannister P, Sheridan P (1987) Continued growth of a large pituitary prolactinoma despite high dose bromocriptine. Br J Clin Pract $41: 712-713$

Barrow DL, Tindall GT, Kovacs K, Thorner MO, Horvath E, Hoffman JC Jr (1984) Clinical and pathological effects of bromocriptine on prolactin-secreting and other pituitary tumors. J Neurosurg 60:1-7

Bassetti M, Spada A, Pezzo G, Giannattasio J (1984) Bromocriptine treatment reduces the cell size in human macroprolactinomas: a morphometric study. J Clin Endocrinol Metab 58:268273

Breidahl HD, Topliss DJ, Pike JW (1983) Failure of bromocriptine to maintain reduction in size of a macroprolactinoma. Br Med J 287:451-452

Bression D, Brandi AM, Martres MP, Nousbarin A, Cesselin F, Peillon F (1980) Dopaminergic receptors in human prolactinsecreting adenomas: a quantitative study. J Clin Endocrinol Metab 51:1037-1043

Cheyne KL, Lightner ES, Comerci GD (1988) Bromocriptine-unre- sponsive porlactin macroadenoma in a prepuberal female. $\mathrm{J}$ Adolesc Health Care 9:331-334

Chiodini P, Luizzi A, Cozzi R, Verde G, Oppirri G, Dallabonzana O, Spella B, Silverstini P, Borghi G, Lucarelli G, Reiner E, Horonski R (1981) Size reduction of macroprolactinomas by bromocriptine or lisuride treatment. J Clin Endocrinol Metab $52: 727-743$

Ciccarelli E, Ghigo E, Mazza E, Massara F, Lancranjan I, Camanni $F$ (1987) Effects of a new long-acting form of bromocriptine on tumorours hyperprolactinemia. J Endocinrol Invest 10:179182

Corenblum B (1985) The medical treatment of the hypersecreting pituitary gland. Can J Neurol Sci 12:243-250

Corenblum B, Hanley DA (1981) Bromocriptine reduction of prolactinoma size. Fertil Steril 36:716-719

Corenblum B, Taylor PJ (1983) Long-term follow-up of hyperprolactinemic women treated with bromocriptine. Fertil Steril 40:596-599

Cronin MJ (1982) The role and direct measurement of the dopamine receptor(s) in the anterior pituitary. Neuroendocrinol Perspect 1:169-210

Esiri MM, Bevan JS, Burke CW, Adams CB (1986) Effect of bromocriptine treatment on the fibrous tissue content of prolactinsecreting and nonfunctioning macroadenomas of the pituitary gland. J Clin Endocrinol Metab 63:338-388

Fahlbusch R, Buchfelder M, Schnell U (1987) Short-term preoperative treatment of macroprolactinomas by dopamine agonists. J Neurosurg 67:807-815

Grossman A, Ross R, Was JAH, Besser GM (1986) Depot-bromocriptine treatment for prolactinomas and acromegaly. Clin Endocrinol 24:231-238

Hassoun J, Jaquet P, Devictor B, Andonian C, Crisoli F, Gunoz G, Toga M (1985) Bromocriptine effects on cultured human prolactin-producing pituitary adenomas: in vitro ultrastructural, morphometric, and immunoelectron microscopic studies. J Clin Endocrinol Metab 61:686-692

Horvath E, Kovacs K (1986) Pathology of prolactin cell adenomas of the human pituitary. Semin Diagn Pathol 3:4-17

Horvath E, Kovacs K, Killinger DW, Gonzalez J, Smith HS (1988) Diverse ultrastructural response to dopamine agonist medication in human pituitary prolactin cell adenomas. In: Hoshino $\mathrm{K}$ (ed) Prolactin gene family and its receptors. Elsevier, Amsterdam, pp 307-311

Johnston DG, Prescott RWG, Kendall-Taylor P, Hall K, Crombie AL, Hall R, McGregor A, Watson MJ, Cook DB (1983) Hyperprolactinemia. Long-term effects of bromocriptine. Am J Med $75: 868-874$

Johnston DG, Hall K, Kendall-Taylor P, Patrick D, Watson M, Cook DR (1984) Effect of dopamine agonist withdrawal after long-term therapy in prolactinomas. Studies with high-definition computerized tomography. Lancet II:187-192

Jordan RM, Kohler PO (1987) Recent advances in diagnosis and treatment of pituitary tumors. Adv Intern Med 32:299-323

Koga M, Nakao H, Arao M, Sato B, Noma K, Morimoto Y, Kishimoto S, Mori S, Nozumi T (1987) Demonstration of specific dopamine receptors on human pituitary adenomas. Acta Endocrinol (Copenh) 114:595-602

Kovacs K, Horvath E (1986) Tumors of the pituitary gland. Atlas of tumor pathology, fascicle XXI, 2nd series. Armed Forces Institute of Pathology, Washington, D.C., pp 96-115

Kovacs K. Lloyd R, Horvath E, Asa SL, Stefaneanu L, Killinger DW, Smyth HS (1989) Silent somatotroph adenomas of the human pituitary. A morphologic study of three cases including immunocytochemistry, electron microscopy in vitro examination, and in situ hybridization. Am J Pathol 134:345-353

Kupersmith MJ, Kleinburg D, Warren FA, Budzilovitch G, Cooper $P$ (1989) Growth of prolactinoma despite lowering of serum prolactin by bromocriptine. Neurosurgery $24: 417-423$

Landolt AM, Osterwalder V (1984) Perivascular fibrosis in prolactinoma: is it increased by bromocriptine. $\mathrm{J}$ Clin Endocrinol Metab 58:1179-1183 
Landolt AM, Osterwalder V, Landolt TA (1987) Storage and release of secretory granules in human prolactinomas: modification by bromocriptine. J Endocrinol 113:495 499

Liuzzi A, Dallabonzana D, Oppizzi G, Verde GG, Gozzi R, Chiondini P, Luccarelli G (1985) Low doses of dopamine agonists in the long-term treatment of macroprolactinomas. $\mathrm{N}$ Engl $\mathrm{J}$ Med 313:656-659

Maurer RA (1980) Dopaminergic inhibition of prolactin synthesis and prolactin messenger RNA accumulation in cultured pituitary cells. J Biol Chem 255:8092-8097

McGregor AM, Scanlon MR, Hall R, Hall K (1979) Effects of bromocriptine on pituitary tumour size. Br Med J 2:700-703

Molitch ME (1989) Management of prolactinomas. Annu Rev Med 40:255-232

Molitch ME, Elton RL, Blackwell RE, Caldwell B, Chang RJ, Jaffe R, Joplin G, Robbins RJ, Tyson J, Thorner MO (1985) The bromocriptine study group. Bromocriptine as primary therapy for prolactin-secreting macroadenomas: results of a prospective multicenter study. J Clin Endocrinol Metab 60:698705

Montini M, Pagani G, Gianol D, Pagani MD, Sahnoraighi M, Ferrari L, Lancranjan I (1986) Long-lasting suppression of prolactin secretion and rapid shrinkage of prolactinomas after a long-acting injectable form of bromocriptine. J Clin Endocrinol Metab 63:266-268

Moriondo P, Travaglini P, Nissinm M, Conti A, Faglia G (1985) Bromocriptine treatment of microprolactinoms: evidence of stable prolactin decrease after drug withdrawal. J Clin Endocrinol Metab 60:764-772

Nabarro JDN (1982) Pituitary prolactinomas. Clin Endocrinol $17: 129-155$

Nillius SJ, Bergh T, Lundberg PO, Stahle J, Wide L (1978) Regression of a prolactin-secreting pituitary tumor during long-term treatment with bromocriptine. Fertil Steril 30:710-712

Rengachary SS, Tomita T, Jefferies BF, Watanabe I (1982) Structural changes in human pituitary tumor after bromocriptine therapy. Neurosurgery $10: 242-251$
Saitoh Y, Mori S, Arita N, Hayakawa T, Mogani H, Matsumoto $\mathrm{K}$, Mori H (1986) Cytosuppressive effect of bromocriptine on human prolactinomas: stereological analysis of ultrastructural alterations with special references to secretory granules. Cancer Res 46:1507-1512

Schettini G, Lombardi G, Merola B, Miletto P, Fariello C, Cirillo S, Fusco R, Lancranjan I (1988) Effectiveness of a single injectable dose of bromocriptine long acting in the treatment of macroprolactinomas. J Endocrinol Invest 11:47-51

Schottke H, Saeger W, Ludecke DK, Caselitz J (1986) Ultrastructural morphometry of prolactin secreting adenomas treated with dopamine agonists. Pathol Res Pract 181:280-290

Thorner MO, Marin KH, Rogol AD, Morris JL, Perryman RL, Conway BP, Howards SS, Wolfman MG, MacLeod RM (1980) Rapid regression of pituitary prolactinomas during bromocriptine treatment. J Clin Endocrinol Metab 51:438-445

Thorner MO, Perryman RL, Rogol AD, Gunay BP, MacLeod RM, Logan IS, Morris JL (1981) Rapid changes in prolactinoma volume following withdrawal and reinstitution of bromocriptine. J Clin Endocrinol Metab 53:480-483

Tindall GT, Kovacs K, Horvath E, Thorner MO (1982) Human prolactin-producing adenomas and bromocriptine: a histological, immunocytochemical, ultrastructural and morphometric study. J Clin Endocrinol Metab 55:1178-1183

Vance ML, Thorner MO (1987) Prolactinomas. Endocrinol Metab Clin North Am 16:731-753

Wang CV, Lam KSL, Ma JTC, Chan T, Liu MY, Yeung RTT (1987) Long-term treatment of hyperprolactinaemia with bromocriptine: effect of drug withdrawal. Clin Endocrinol 27:363371

Verlant JW van't, Lancranjan I, Hendriks MJ, Croughs RJM (1988) Primary treatment of macroprolactinomas with Parlodel LAR. Acta Endocrinol (Copenh) 119:51-55

Zarate A, Canales ES, Cano C, Philonieta CJ (1983) Follow-up of patients with prolactinomas after discontinuation of longterm therapy with bromocriptine. Acta Endocrinol (Copenh) $104: 139-142$ 